\title{
EFFECT OF PH AND IMPROVEMENT IN VIOLET REMAZOL DYE REMOVAL FROM WATER BY Eichhornia Crassipes (water hyacinth)
}

\author{
EFEITO DO pH E MELHORIA NA REMOÇÃO DO CORANTE VIOLETA REMAZOL EM ÁGUA \\ POR Eichhornia Crassipes (aguapé)
}

\section{EFECTO DEL pH Y LA MEJORA EN REMOVAL TINTE DE REMAZOL VIOLET DEL AGUA POR Eichhornia Crassipes (jacinto de agua)}

Rosiane F. do Nascimento Cícero W. B. Bezerra Hildo A. S. Silva Mário Sérgio Schultz

Sirlane A. A. Santana

\begin{abstract}
In this work water hyacinth (Eichhornia crassipes) was used as adsorbent for aqueous Violet Remazol 5R (VR 5) solutions. In order to obtain the best conditions for the removal, the pH influence, time of contact and concentration were verified. The adsorption showed itself highly dependent of the $\mathrm{pH}$, being the maximum adsorption was observed $\mathrm{pH}$ 1.0. In the kinetic experiments, the batchwise method was used with concentrations of 250 and $1000 \mathrm{mg} \mathrm{dm}-3$, and after the time of contact the concentration was determined by spectrophotometry. An adequation of the models of pseudo-first and second order was made based on the results that were found. The second order model was the most suitable in both concentrations, with $\mathrm{R}^{2}=0.999$. The Langmuir, Freundlich, Sips and Temkin models were used to analyze the experimental data in its linearized mode. The Langmuir model was the most appropriate. In the conditions studied, the removal of textile dye Violet Remazol 5R by water hyacinth showed good results, making it possible to use this material as an alternative way to remove dyes from textile effluents.
\end{abstract}

Keywords: Water hyacinth (Eichhornia crassipes). Textile dye. Adsorption.

Resumo: Neste trabalho foi utilizado o aguapé (Eichhornia crassipes) como adsorvente de soluções aquosas de Violeta Remazol 5R (VR 5). De modo a obter as melhores condições para a remoção foram verificados, a influência do pH, tempo de contato e a concentração. A adsorção mostrou-se altamente dependente do $\mathrm{pH}$, sendo que a adsorção máxima foi observada $\mathrm{pH} 1,0$. Nas experiências de cinética, o método de batelada foi utilizado nas concentrações de 250 e $1000 \mathrm{mg} \mathrm{dm}^{-3}$, e após o tempo de contato com a concentração foi determinada por espectrofotometria. Uma adequação dos modelos de pseudo-primeira ordem e segunda foi feita com base nos resultados que foram encontrados. O modelo de segunda ordem foi o mais adequado em ambas às concentrações, com R $2=0,999$. Os modelos de Langmuir, Freundlich, Sips e Temkin foram utilizados para analisar os dados experimentais em seu modo linear. O modelo de Langmuir foi o mais adequado. Nas condições estudadas, a remoção de corante têxtil Violeta Remazol 5R por aguapé mostrou bons resultados, tornando possível a utilização deste material como uma forma alternativa para remover corantes de efluentes têxteis.

Palavras-chave: Aguapé (Eichhornia crassipes). Corante têxtil. Adsorção.

Resumen: En este trabajo fue utilizado el jacinto de agua (Eichhornia crassipes) como adsorvente para la remoción del colorante textil aniónico Violeta de Remazol 5R de soluciones acuosas. Con el objetivo de encontrar condiciones mas adecuadas para la remoción, se verificó la influencia del pH, tiempo de contacto y concentración. La adsorción se mostró fuertemente dependiente del $\mathrm{pH}$, presentando una adsorción máxima a $\mathrm{pH} 1,0$. Para los experimentos de cinética se utilizou el método de lote en las concentraciones de 250 y $1000 \mathrm{mg} \mathrm{dm}^{-3}$, y después del tiempo de contacto se realizó la determinación de la concentración atraves de espectrofotometria. Con los resultados conseguidos se hizo una adaptación a los modelos de pseudo-primera orden y segunda orden, con $\mathrm{R}^{2}=0,999$. Los modelos de Langmuir, Freundlich e Temkin, fueron utilizados para analizar los datos experimentales en su forma linealizada. El modelo que major se adaptó fue el de Langmuir. Bajo las condiciones de estudio, la remoción del colorante textil aniónico Violeta de Remazol 5R por jacinto de agua mostró buenos resultados, lo que permitiria que pueda ser utilizado como una alternativa para la remoción de colorantes en efluentes textiles.

Palabras clave: Jacinto de agua (Eichhornia crassipes). Colorante textil. Adsorción.

\footnotetext{
*Artigo recebido em agosto de 2013
}

Aprovado em outubro de 2013 


\section{INTRODUCTION}

The textile industries produce a lot of wastewater, which contains a number of contaminants, including acidic or caustic dissolved solids, toxic compounds, and many different dyes. The extensive use of dyes represents a concern in public health and serious environmental problems due to their persistence in nature and characteristics of non biodegradable (HU et al., 2010).

Conventional methods used for dye removal from industrial effluents include coagulation/flocculation, anaerobic degradation, photocatalysis, advanced oxidation processes (AOPs), filtration and adsorption. In addition, most of these methods are often expensive or ineffective, especially for dye removal from dilute solutions (GUPTA; SUHAS, 2009).

The utilization of adsorbents for dye removal from wastewater is an efficient treatment processes, which can be used to remove different types of materials, especially non degradable. The most commonly used adsorbent is activated carbon, however, its use has several drawbacks such as low retention capacity of bulky adsorbates and operational cost dearly (GUPTA; SUHAS, 2009).

Some low-cost lignocellulosic materials have been used as biosorbents for the adsorption of cationic and anionic dye (SALLEH et al., 2011). The exploration and appropriate use of these biomaterials bring great economic and social benefits to mankind, helping to minimize environmental and energy issues. Brazil has a high potential for the production of lignocellulosic fiber that have shown many potential applications in removing pollutants (SANTANA et al., 2010; VIEIRA et al., 2010; VIEIRA et al., 2011).

Water hyacinth (Eichhornia crassipes) is one of the most abundant species in the Amazon and its distribution extends to all tropical regions of the planet (SCULTHORPE, 1985). Water hyacinth grows rapidly on the surface of waterways, forming a dense mat which depletes the surrounding environment of essential nutrients. These properties, rarely encountered in other plant systems, are features of an ideal feedstock for renewable biomass (HRONICH et al., 2008). The same plant has demonstrated an amazing ability to absorb and concentrate many toxic metals from aquatic environments. Consequently, research activity on utilization of the plant has been registered over the last few decades (ABDEL-SABOUR, 2010; CHEN et al., 2010; MAHAMADI, 2011). In recent years, was studied the utilization of water hyacinth in the removal of color from wastewater of textile dyeing processes, for cationic dye (TARAWOU; HORSFALL; VICENTE, 2007; EL-KHAIARY, 2008; RENGANATHAN et. al., 2008). Thus, the purpose of this paper is to characterize by FTIR spectral analysis and to investigate the efficiency of water hyacinth as adsorvent in removal of anionic textile dye Violet Remazol $5 R$ in aqueous solution, contributing to the use of this material useful for the removal of pollutants in aquatic environments.

\section{MATERIALS AND METHODS}

The dye Violet Remazol 5R (VR 5) was provided by Indústria Toalhas São Carlos, state of São Paulo, Brazil. The chemical structure is shown in figure 1 . The dye was chemical product of analytical grade and was used without further purification.

Figure 1 - Chemical structure of dye Violet Remazol 5R (VR 5)

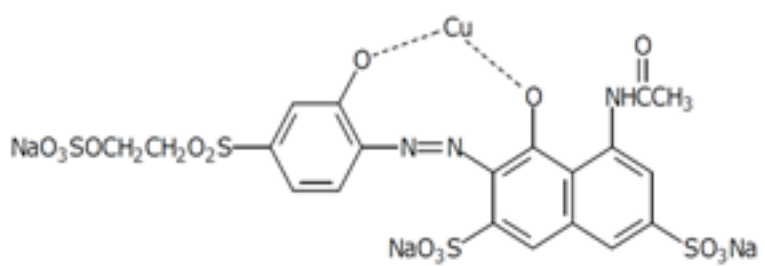

Source: Costa et al. (2009)

The water hyacinth was acquired in the city of São Luís, Maranhão state, Brazil. The material was washed thoroughly with water to for several times to remove matter and all dirt particles. It was then dried at $50{ }^{\circ} \mathrm{C}$ for 24 hours. The dried material was then crushed, sieved in the 0.088 to $0.177 \mathrm{~mm}$ range.

Infrared spectrum was obtained in the 4000 to $400 \mathrm{~cm}^{-1}$ range by accumulating 32 scans by Fourier transform infrared spectroscopy (FTIR), on a MB-Bomem spectrophotometer, using $\mathrm{KBr}$ pellets with a resolution of 4 $\mathrm{cm}^{-1}$. Spectroscopy in the visible region was obtained in a quartz cell with path length of $1.0 \mathrm{~mm}$. The spectra were recorded on a Cary 50 Varian spectrophotometer apparatus at 540 $\mathrm{nm}$, maximum wavelength for VR 5 .

\subsection{Point of zero charge}

The point of zero charge of water hyacinth was determined by the solid addition method (SANTANA et al., 2010). To a series of $100 \mathrm{~cm}^{3}$ of conical flasks were transferred $25.0 \mathrm{~cm}^{3}$ of $0.1 \mathrm{~mol} \mathrm{dm}^{-3} \mathrm{KCl}$ aqueous solution, with $\mathrm{pH}$ varying of 1 to 12 . The initial $\mathrm{pH}$ value $(\mathrm{pHi})$ of each solution was adjusted by adding either $0.10 \mathrm{~mol} \mathrm{dm}^{-3}$ of hydrochloric acid or sodium hydroxide. The $\mathrm{pH}$ measurements were obtained using a DM-21 Digimed instrument. The pHi's of the solutions were then accurately measured and $100.0 \mathrm{mg}$ of water hyacinth was added to each flask. The suspensions were shaken for $24 \mathrm{~h}$ and then the $\mathrm{pH}$ values of the supernatant were measured. The difference between the initial and final $\mathrm{pH}$ value, $(\mathrm{pHi}-$ $\mathrm{pHf}$ ), was plotted against $\mathrm{pHi}$ and the point of intersection of the resulting for null $\Delta \mathrm{pH}$ corresponds to point zero charge, $\mathrm{pHpzc}$. 


\subsection{Effect of $\mathrm{pH}$}

The effect of $\mathrm{pH}$ on the sorption was performed by an using identical series of flasks containing $100.0 \mathrm{mg}$ of biomaterial with 25.0 $\mathrm{cm}^{3}$ of the $250 \mathrm{mg} \mathrm{dm}^{-3}$ VR 5 dye solution, maintaining stirring for $24 \mathrm{~h}$ at $25{ }^{\circ} \mathrm{C}$. $\mathrm{pH}$ in the range from 1.0 to 6.0 was adjusted when necessary with $0.10 \mathrm{~mol} \mathrm{dm}^{-3}$ hydrochloric acid or sodium hydroxide solutions. At the end of this process, the solid was separated by centrifugation and the dye concentration found in the supernatant was determined by using a Varian AA 50 spectrophotometer at a wavelength of $540 \mathrm{~nm}$.

The amount of dye adsorbed, qe $\left(\mathrm{mg} \mathrm{g}^{-1}\right)$, was obtained with equation 1 :

$$
q_{e}=\frac{\left(C_{i}-C_{f}\right)}{W} \times V
$$

Where $\mathrm{Ci}$ and $\mathrm{Cf}$ are the initial and final dye concentrations at equilibrium in the aqueous phase $\left(\mathrm{mg} \mathrm{dm}^{-3}\right)$, respectively, $\mathrm{V}$ is volume of dye solution $\left(\mathrm{dm}^{3}\right)$ and $\mathrm{W}(\mathrm{g})$ is the amount of water hyacinth employed.

\subsection{Kinetics and isotherms}

For the kinetics studies $100.0 \mathrm{mg}$ of adsorbent were mixed with $25.0 \mathrm{~cm}^{3}$ aqueous dye solutions of known concentration ( 250 and $1000 \mathrm{mg} \mathrm{dm}^{-3}$ ) at $25 \pm 1{ }^{\circ} \mathrm{C}$. The flasks were capped and the system was stirred for variable times. For all experiments the aqueous solution $\mathrm{pH}$ was adjusted at 2.0, using hydrochloric acid. After centrifugation, the dye was determined as previously described. To investigate the possible mechanism of sorption, some kinetic models were used: pseudo-first order, pseudo-second order kinetics and intraparticle diffusion (ACHARYA et al., 2009), represented by linear equations (2) to (4), respectively:

$$
\begin{aligned}
& \ln \left(q_{\theta}-q_{t}\right)=\ln q_{\theta}-k_{1} t \\
& \frac{t}{q_{t}}=\frac{1}{k_{2} q_{\theta}^{2}}+\frac{1}{q_{\theta}} \\
& q_{t}=k_{d i f} t^{1 / 2}+I
\end{aligned}
$$

where qe and qt are the amounts of dye sorbed $\left(\mathrm{mg} \mathrm{g}^{-1}\right)$ on water hyacinth at equilibrium and at time $\mathrm{t}(\mathrm{min})$, and $\mathrm{k} 1\left(\mathrm{~min}^{-1}\right)$ and $\mathrm{k} 2\left(\mathrm{~g} \mathrm{mg}^{-1} \mathrm{~min}^{-1}\right)$ are pseudo-first order and pseudo-second order rate constants, respectively; kdif ( $\mathrm{mg} \mathrm{g}^{-1} \mathrm{~min}^{-0.5}$ ) is the intraparticle diffusion rate constant and I, constant related to the diffusion resistance of the adsorbed species due to the effect of interface.

The isotherms were obtained using a batchwise method, which consisted in suspending a series of $100.0 \mathrm{mg}$ of water hyacinth in 25.0 $\mathrm{cm}^{3}$ of aqueous dye solutions having different concentrations, varying from 50 to $1000 \mathrm{mg}$ $\mathrm{dm}-3$ under equilibrium time and optimal $\mathrm{pH}$ conditions, previously established. At the end of this process, the solid was separated by centrifugation and the dye amount adsorbed was determined as previously described. The isotherms of the Langmuir, Freundlich, Temkin and Sips (CHOWDHURY; SAHA, 2011; GILES; D'SILVA; EASTON, 1974; FEBRIANTO et al., 2009) models in their linear forms, equations (5) to (8) respectively, were applied to the equilibrium data of sorption of Violet Remazol $5 \mathrm{R}$ on water hyacinth.

$$
\frac{C_{e}}{q_{e}}=\frac{1}{q_{m} K_{L}}+\frac{1}{q_{m}} C_{\theta}
$$

$$
\log q_{\theta}=\frac{1}{n_{F}} \log C_{\theta}+\log K_{F}
$$

$$
\begin{aligned}
& q_{\theta}=\left(\frac{R T}{b_{T}}\right) \ln K_{T}+\left(\frac{R T}{b_{T}}\right) \ln C_{\theta} \\
& \frac{C_{\theta}^{1 / n_{s}}}{q_{\theta}}=\frac{1}{q_{m}} C_{\theta}^{1 / n_{s}}+\frac{1}{q_{m} K_{S}}
\end{aligned}
$$

where $q_{e}\left(\mathrm{mg} \mathrm{g}^{-1}\right)$ is the amount of dye sorbed per unit mass of sorbent, $\mathrm{q}_{m}$ is the maximum Langmuir sorption capacity $\left(\mathrm{mg} \mathrm{g}^{-1}\right)$, $\mathrm{Ce}$ is the equilibrium concentration $\left(\mathrm{mg} \mathrm{dm}^{-3}\right)$, $\mathrm{n}_{\mathrm{F}}$ is interpreted as a factor of heterogeneity, ns is a parameter related to the characteristics of adsorption sites, $\mathrm{K}_{\mathrm{L}}\left(\mathrm{dm}^{3} \mathrm{mg}^{-1}\right), \mathrm{K}_{\mathrm{F}}\left[\mathrm{mg} \mathrm{g}^{-1}\right.$ $\left.\left(\mathrm{dm}^{3} \mathrm{mg}^{-1}\right)^{1 / \mathrm{n}}\right], \mathrm{K}^{\top}\left(\mathrm{L} \mathrm{g}^{-1}\right)$ and $\mathrm{K}_{\mathrm{s}}\left(\mathrm{L} \mathrm{mg}^{-1}\right)^{-1 / n s}$ are the Langmuir, the Freundlich, the Temkin and the Sips constants, respectively.

\section{RESULTS AND DISCUSSION}

\subsection{Characterization of the sorbent}

Water hyacinth, as shown in Figure 2, presented bands attributed to $\mathrm{O}-\mathrm{H}$ stretching at 3200 to $3600 \mathrm{~cm}^{-1}$. The stretching bands of $\mathrm{C}-\mathrm{H}$ and $\mathrm{CH}_{2}$ appear in the 2900 to $3000 \mathrm{~cm}^{-1}$ interval and the corresponding deformation is at 1453 and $1373 \mathrm{~cm}^{-1}$. The band at $1639 \mathrm{~cm}^{-1}$ corresponds to $\mathrm{H}-\mathrm{O}-\mathrm{H}$ bending of absorbed water while that the band at $1316 \mathrm{~cm}^{-1}$ is as- 
signed to $\mathrm{CH}_{2}$ rocking vibration. Band at 1248 $\mathrm{cm}^{-1}$ is attributed to $\mathrm{C}-\mathrm{O}$ stretching in cellulose and hemicelluloses. The spectra show also the prominent peak with maximum near $1030 \mathrm{~cm}^{-1}$ due to $\mathrm{C}-\mathrm{O}$ vibrations in the cellulose pyranoside units. The bands associated with tetra- and trisubstituted benzene out of plane vibrations are assigned at 913 and $774 \mathrm{~cm}^{-1}$, respectively (TSERKI et al., 2005).

Figure 2 - FTIR spectrum of the water hyacinth

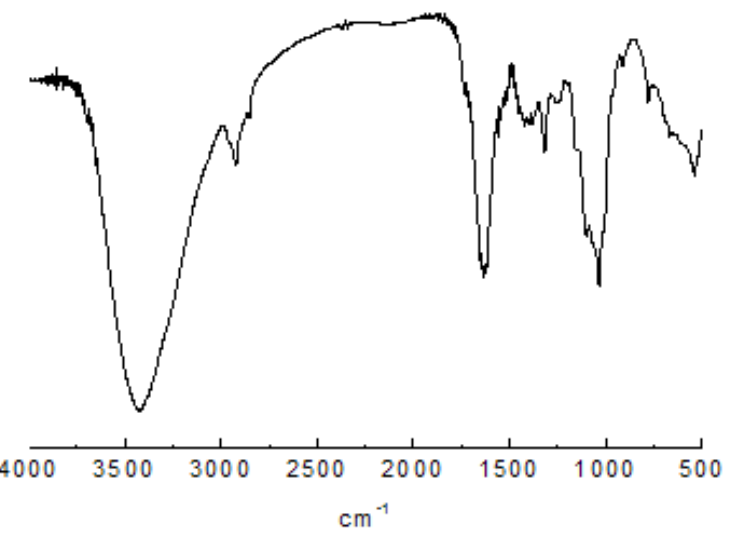

Source: developed by the authors.

\section{$3.2 \mathrm{pH}$ effect}

The $\mathrm{pH}$ of the solution affects the surface charge of the adsorbents as well as the degree of ionization and speciation of different pollutants (EL-SAID; BADAWY; GARAMON, 2010). Since the efficiency of sorption processes is strongly dependent on the $\mathrm{pH}$, comparative experiments were performed at $\mathrm{pH}$ between 1 and 6 (Figure 3 ). The adsorption of the VR 5 on water hyacinth increases with the decrease in $\mathrm{pH}$ value and reaches maximum values at $\mathrm{pH} 1.0(66 \%)$ and $2.0(61 \%)$. Kinetic studies and adsorption isotherms were performed at $\mathrm{pH} 2.0$, less drastic condition, with slight variation in results when compared to $\mathrm{pH} 1.0$.

It must be noted that the surface of the adsorbent changes its polarization according to the value of the $\mathrm{pH}$ of the solution and to the pHpzc of the solid. At pH lower than pHpzc the surface becomes positively charged and it is the opposite for $\mathrm{pH}$ higher than pHpzc. As noted in figure 4 , the surface of water hyacinth is protonated in values $\mathrm{pH}$ smaller than 6.3, favoring the adsorption of compounds with negative charge. For values of $\mathrm{pH}$ greater than this, the surface of the water hyacinth becomes deprotonated, favoring the attraction of positive charges. The studied dye had several functional groups such as $\mathrm{OH}$ - or expose negatively sulfonate $\mathrm{SO}_{3}{ }^{2}$ - charged groups, then, it is expected that at $\mathrm{pH}$ lower than 6.3 to adsorption of anionic dyes is favored. The sorption profile of VR 5 on water hyacinth as a function of the initial $\mathrm{pH}$ could also be explained on the basis of surface charge density of functional groups and the decrease in adsorption with increase in initial $\mathrm{pH}$ can be attributed to the fact that the negatively charged anionic dyes are repulsed at higher $\mathrm{pH}$ values, which results are in agreement with earlier reports (SANTANA et al., 2010).

Figure 3 - Effect of pH on Violet Remazol sorption by water hyacinth of aqueous solution ( 24 hours at $25 \pm 1$ ${ }^{\circ} \mathrm{C}$, [VR 5R] $=250 \mathrm{mg} \mathrm{dm}^{-3}$ )

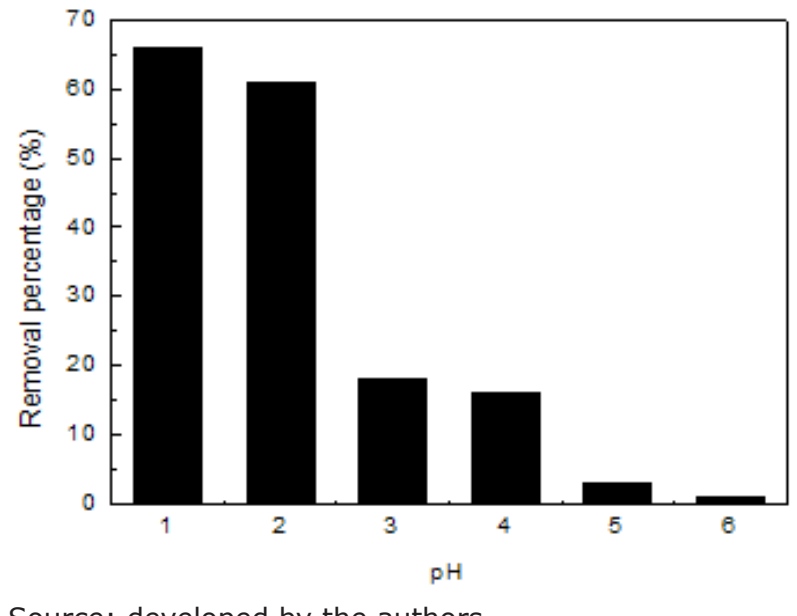

Source: developed by the authors.

Figure 4 - Point of zero charge (pHpzc) of water hyacinth

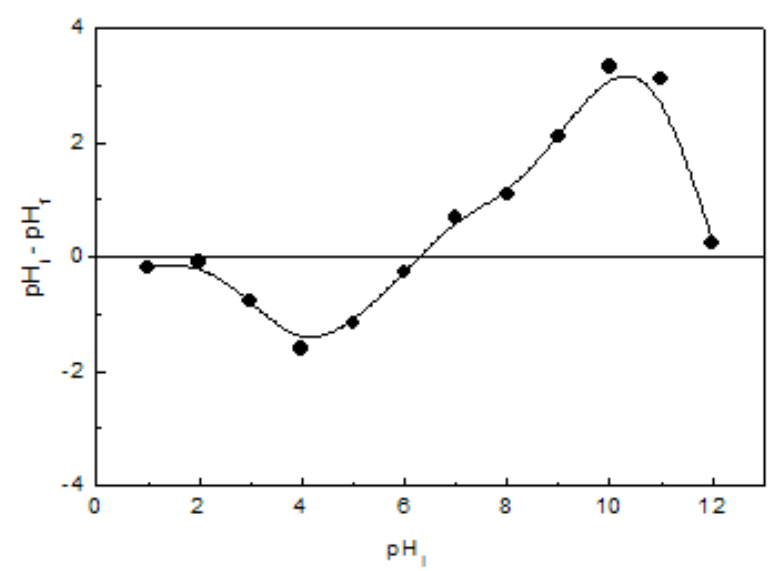

Source: developed by the authors.

\subsection{Kinetics of adsorption}

The adsorption capacity versus adsorption time plot is shown in figure $5(\mathrm{a})$. Equilibrium is achieved in about $120 \mathrm{~min}$ at $25 \pm 1^{\circ} \mathrm{C}$ with a dose of $100 \mathrm{mg}$ of adsorbent in $25 \mathrm{dm}^{-3}$ of dye solution in concentrations of 250 and $1000 \mathrm{mg}$ $\mathrm{dm}^{-3}$, indicating that the equilibration time is not influenced by the concentration of the dye.

The rate constant for the first-order equation was determined from the slope of the plot In $\left(q_{e}-q_{t}\right)$ versus time. If first-order kinetics is applicable to the system under study, the plot of In $\left(\mathrm{q}^{\mathrm{e}}-\mathrm{q}_{\mathrm{t}}\right)$ versus time, as represented by Eq. (2), should give a linear relationship. Further, the $q_{e}$ obtained from the plot should also be close to the $\mathrm{q}_{\mathrm{e}}$ experimentally obtained 
from the dye solution. Even though the correlation coefficient of the first-order equation was reasonable $\left(R_{2}=0.980\right)$, the calculated value of qe from the first order kinetic plot was far too small $\left(q_{\mathrm{e}}=27.6 \mathrm{mg} \mathrm{g}^{-1}\right)$, compared to the experimental values $\left(\mathrm{q}_{\text {e,exp }} \approx 40 \mathrm{mg} \mathrm{g}^{-1}\right)$. The second-order sorption rate constant and $\mathrm{q}_{\mathrm{e}}$ were determined from the slope and intercept of $t / q_{t}$ versus time plot (Figure $5 \mathrm{~b}$ ) and the correlation coefficients for the linear plot are better than 0.99 . The calculated $q_{e}$ value from the pseudo-second-order model $\left(\mathrm{q}_{\mathrm{e}}=41.6 \mathrm{mg}\right.$ $\mathrm{g}^{-1}$ ) is in good agreement with experimental $\mathrm{q}_{\mathrm{e}}$ values. This suggests that the sorption system followed the pseudo second-order model. The applicability of the pseudo second-order model suggests that chemisorption might be the rate-limiting step that controls the adsorption processes. In general, this model has the following advantage: the adsorption capacity, the pseudo second-order rate constant and the initial adsorption rate can be determined ( $\mathrm{HO}$; MCKAY, 2006).

Figure 5 - Kinetics for Violet Remazol 5R (VR 5) adsorptions by water hyacinth (A) and fit the pseudosecond order models (B). (•) $250 \mathrm{mg} \mathrm{dm}-3$; ( $\mathbf{\Delta}$ ) 1000 $\mathrm{mg} \mathrm{dm}^{-3}$
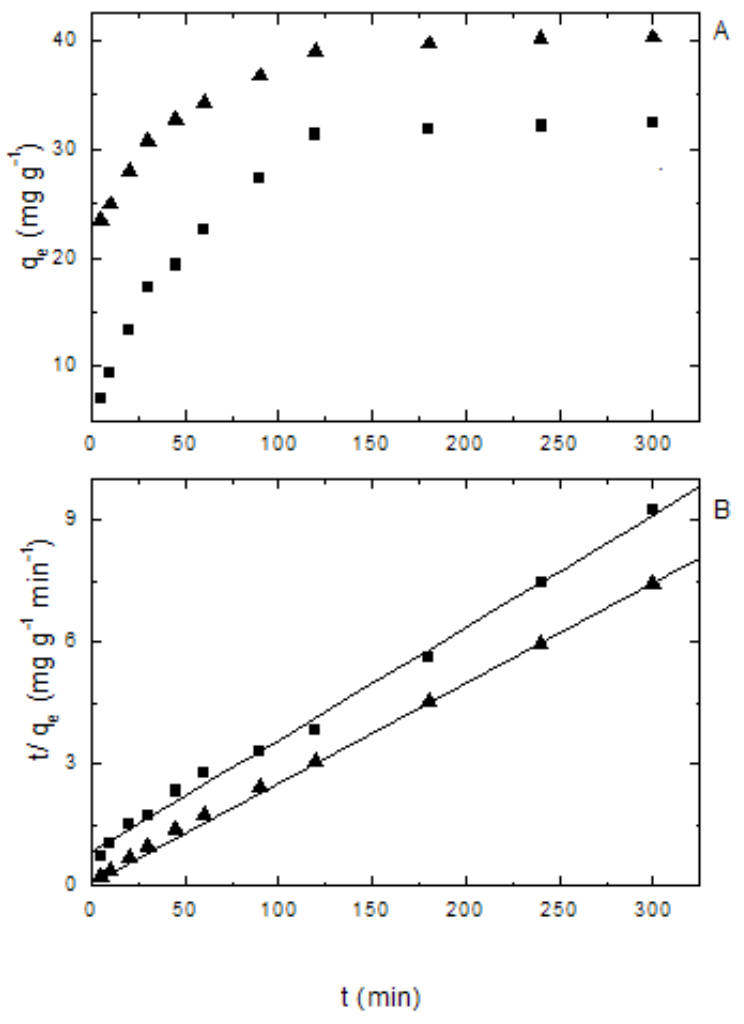

Source: developed by the authors.

Figure 6 shows that intraparticle diffusion adsorption VR 5 occurs in three characteristic stages. The first stage is characterized by the onset of a rapid diffusion of the adsorbate toward the outer surface of the adsorbent. The second stage is represented by a straight linear profile that presents a gradual adsorption, where intraparticle diffusion begins to decay due to the low concentration gradient of the solute, as well as a reduced availability of sites for adsorption. The third stage is characterized by a line indicating the remaining balance, as observed at both concentrations studied.

Figure 6 - Intraparticle diffusion model for Violet Remazol sorption from aqueous solution by water hyacinth

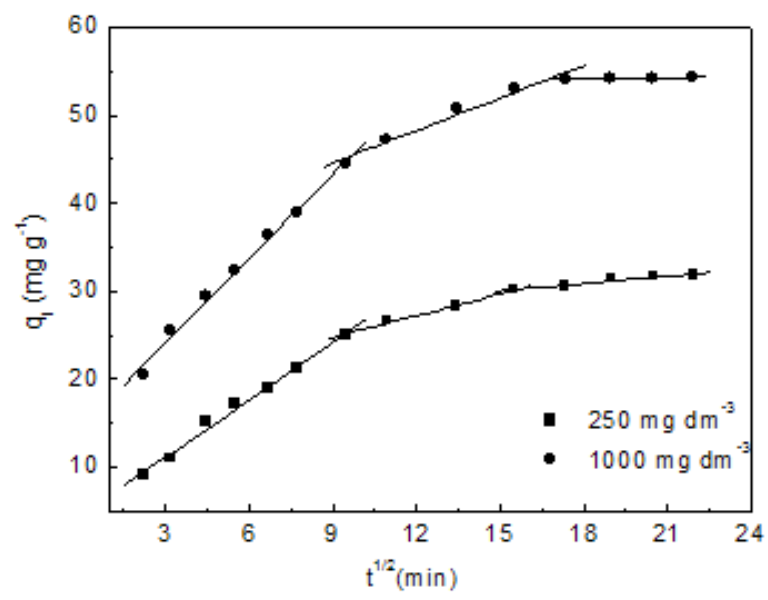

Source: developed by the authors.

By analyzing the values of intraparticle diffusion constants shows that there is a significant decrease with changing steps, the first stage $>$ second stage $>$ third stage (ranging from 2.18 to 0.8 and 2.19 to 0.05 for concentrations of 250 and $1000 \mathrm{mg} \mathrm{dm}^{-3}$, respectively), indicating a gradual increase of the diffusion resistance in the interface provided between the dye and the surface of the adsorbent, which is assigned to the saturation of the adsorbents surface, the system reaching equilibrium.

Despite the high values of the linear regression coefficients for the intraparticle diffusion $\left(R_{2} \approx 0.99\right)$, it contributes only at the beginning of the adsorption process, and the overall mechanism of the adsorption is controlled by the second-order chemical process.

\subsection{Sorption isotherms}

The adsorption isotherm represents the concentrations of dye sorbed at equilibrium $\left(\mathrm{q}_{\mathrm{e}}\right)$ according to the amount adsorbed per gram of sorbent. Profiles of the isotherm of VR 5 adsorption from aqueous solution on water hyacinth is shown in figure 7 . From the adsorption curves the plateau was progressively approached as the concentration investigated increased. Analyses of correlation coefficients showed that the Langmuir isotherm provided the best fit for experimental data, shown in figure 7 . The Langmuir isotherm parameter qm indicates the maximum adsorption capacity of the material, in other words, the adsorption of dye at high concentration (GILES; D'SILVA; EASTON, 1974). From the correlation 
coefficients, $R_{2}$, we can compare the applicability of the isotherm equation. The Langmuir isotherm was obeyed better than the Freundlich, Sips and Temkin isotherms, as is evident from the values of the regression coefficients (Table 1). The Langmuir model is an indication of surface homogeneity of the adsorbent. Most of the reported dyes systems suggest the applicability of the Langmuir equation, which assumes there are monolayer coverage and constant sorption energy on the sorbent surface (GILES, D'SILVA; EASTON, 1974). The adsorption results for VR 5 on water hyacinth (48.9 $\mathrm{mg} \mathrm{g}^{-1}$ ) were higher than those reported for anionic dyes adsorbed on peanut hulls (15.6 $\mathrm{mg} \mathrm{g}^{-1}$ ) (GONG et al., 2005), wheat bran (10.5 mg g ${ }^{-1}$ ) (ÇICEK et al., 2007), almond hulls (20.5 $\mathrm{mg} \mathrm{g}^{-1}$ ) (ARDEJANI et al., 2008) and Brazil nuts ( $7.81 \mathrm{mg} \mathrm{g}^{-1}$ ) (BRITO et al., 2010), which suggests that this biomaterial have high performance for dye removal at the solid/liquid interface.

The results from the Temkin model presented a poor linear fit for VR 5 dye adsorption on water hyacinth. A summary of the parameters calculated from the models are listed in table 1. Based on the correlation coefficients, the Langmuir, Freundlich and Sips models presented the values very close, in adsorption dye on water hyacinth. But when comparing the amount adsorbed obtained experimentally and calculated, we can identify a relative closeness between the values. Furthermore, Langmuir isotherm model was observed for adsorption of dyes in various biosorbent, such as palm kernel fiber (OFOMAJA; $\mathrm{HO}, 2007$ ) thuja (AKAR et al., 2008) and cottonseed hulls (TUNÇ; TANACI; AKSU, 2009).

\section{CONCLUSION}

Our study showed that the amount of dye adsorbed by the water hyacinth, an aquatic plant macrophyte, was found to vary with initial Violet Remazol 5R concentration, $\mathrm{pH}$ and contact time. Also, the decrease in $\mathrm{pH}$ favored the adsorption process, reaching a maximum value of $66 \%$, that is justified by the point of zero charge $(\mathrm{pHpzc}=6.3)$. By adsorption data was found to follow the pseudo second order kinetics at room temperature and the Langmuir model adsorption showed maximum adsorption $48.9 \mathrm{mg} \mathrm{g}-1$ at $\mathrm{pH}$ 2.0. FTIR analysis revealed structural features such as $\mathrm{O}-\mathrm{H}$ and $\mathrm{C}-\mathrm{H}$ stretching that are characteristic of the chemical fractions of the materials, which can sorb Violet Remazol 5R dye in a process that depends on $\mathrm{pH}$. In view of these results, which indicate the potential of this material for removing dye in water, we suggest their application to adsorption of other dyes, as well as actual samples, and changes in surface for the incorporation of new active sites for specific applications.
Figure 7 - Isotherms and Langmuir adsorption for Violet Remazol 5R onto water hyacinth in aqueous solutions at $25 \pm 1{ }^{\circ} \mathrm{C}$ and $\mathrm{pH} 2$

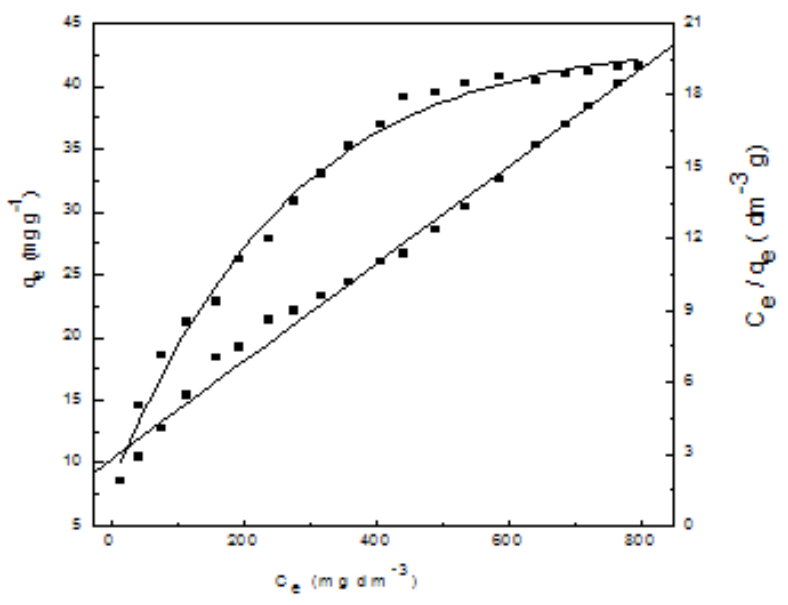

Source: developed by the authors.

Table 1 - Isotherm data for Violet Remazol 5R, using water hyacinth as sorbent at $25 \pm 1^{\circ} \mathrm{C}$ and $\mathrm{pH} 2$. qm $\left(\mathrm{mg} \mathrm{g}^{-1}\right)=$ maximum Langmuir and Sips sorption capacity; $\mathrm{K}_{\mathrm{L}}\left(\mathrm{dm}^{3} \mathrm{mg}^{-1}\right), \mathrm{K}_{\mathrm{F}}\left[\mathrm{mg} \mathrm{g}^{-1}\left(\mathrm{dm}^{3} \mathrm{mg}^{-1}\right)^{1 / \mathrm{n}}\right]$, KS (L mg-1) $-1 / n s=$ Langmuir, Freundlich, Sips and Temkin constants, respectively; $n_{F}$ and $n_{s}$ (dimensionless) $=$ terms used to estimate the heterogeneity for the Freundlich and Sips models, respectively, where a value that deviates from unity indicates heterogeneity of a material; $\mathrm{R}_{2}=$ correlation coefficient.

\begin{tabular}{ccccc}
\hline Parameter & Langmuir & Freundlich & Sips & Temkin \\
\hline $\mathrm{q}_{\mathrm{m}}$ & 48.9 & - & 51.5 & - \\
$\mathrm{K}_{\mathrm{L}}$ & 0.007 & - & - & - \\
$\mathrm{n}_{\mathrm{F}}$ & - & 2.49 & - & - \\
$\mathrm{K}_{\mathrm{F}}$ & - & 3.12 & - & - \\
$\mathrm{n}_{\mathrm{S}}$ & - & - & 120.2 & - \\
$\mathrm{K}_{\mathrm{S}}$ & - & - & 0.011 & - \\
$\mathrm{A}$ & - & - & - & 1.55 \\
$\mathrm{~b}$ & - & - & - & 259.7 \\
$\mathrm{R}^{2}$ & 0.989 & 0.982 & 0.986 & 0.964 \\
\hline
\end{tabular}

Source: developed by the authors.

\section{ACKNOWLEDGMENTS}

The authors are indebted to CAPES and FAPEMA for financial support, and to Indústria de Toalhas São Carlos for donation of the dye samples. 


\section{REFERENCES}

ABDEL-SABOUR, M. F. Water hyacinth: available and renewable resource. Eletronic Journal of Environmental, Agricultural and Food Chemistry, v. 9, n. 11, p. 1746-1759, 2010.

ACHARYA, J. et al. Removal of chromium(VI) from wastewater by activated carbon developed from tamarind wood activated with zinc chloride. Chemical Engineering Journal, v. 150, n.1, p. 25-39, 2009.

AKAR, $T$. et al. Biosorption of a textile dye (acid blue 40 ) by cone biomass of thuja orientalis: estimation of equilibrium, thermodynamic and kinetic parameters. Bioresource Technology, v. 99, n. 8, p. 30573065, 2008.

ARDEJANI, F. D. et al. Adsorption of direct red 80 dye from aqueous solution onto almond shells: effect of $\mathrm{pH}$, initial concentration and shell type. Journal of Hazardous Materials, v. 151, n. 2-3, p. 730-737, 2008.

BRITO, S. M. O. et al. Brazil nut shells as a new biosorbent to remove methylene blue and indigo carmine from aqueous solutions. Journal of Hazardous Materials, v. 174, n. 1-3, p. 84-92, 2010.

CHEN, X. et al. Water hyacinth (eichhornia crassipes) waste as an adsorbent for phosphorus removal from swine wastewater. Bioresource Technology, v. 101, n. 23, p. 9025-9030, 2010.

CHOWDHURY, S.; SAHA, P. D. Biosorption kinetics, thermodynamics and isosteric heat of sorption of $\mathrm{cu}$ (II) ontotamarindus indica seed powder. Colloids and Surfaces B: Biointerfaces, v. 88, n.2, p. 697- 705, 2011.

ÇICEK, F. et al. Low cost removal of reactive dyes using wheat bran. Journal of Hazardous Materials, v. 146, n. 1-2, p. 408-416, 2007.

EL-KHAIARY, M. I. Least-squares regression of adsorption equilibrium data: comparing the options. Journal of Hazardous Materials, v. 158, n. 1, p. 73-87, 2008.

EL-SAID, A. G.; BADAWY, N. A.; GARAMON, S. E. Adsorption of cadmium (II) and mercury (II) onto natural adsorbent rice husk ash (RHA) from aqueous solutions: study in single and binary system. Journal of American Science, v. 12, n. 6, p. 400-409, 2010.
FEBRIANTO, J. et al. Equilibrium and kinetic studies in adsorption of heavy metals using biosorbent: a summary of recent studies. Journal of Hazardous Materials, v. 162, n. 2-3, p. 616-645, 2009.

GILES, C. H.; D'SILVA, A. P.; EASTON, I. A. A. general treatment of the solute adsorption isotherm: part II, experimental interpretation. Journal Colloid Interface Scince, v. 47, p. 766-778, 1974.

GONG, R. et al. Utilization of powdered peanut hull as biosorbent for removal of anionic dyes from aqueous solution. Dyes and Pigments, v. 64, n. 3, p. 187-192, 2005.

GUPTA V. K.; SUHAS. Application of low-cost adsorbents for dye removal: a review. Journal of Environmental Management, v. 90, n. 8, p. 2313-2342, 2009.

HAMEED, B. H.; MAHMOUD, D. K.; AHMAD, A. L. Equilibrium modeling and kinetic studies on the adsorption of basic dye by a low-cost adsorbent: coconut (cocos nucifera) bunch waste. Journal of Hazardous Materials, v. 158, n. 1, p. 65-72, 2008.

HO, Y. S.; MCKAY, G. Sorption of dye from aqueous solution by peat. Chemical Engineering Journal, v. 70, n. 2, p. 115-124, 1998.

HRONICH, J. E. et al. Potential of eichhornia crassipes for biomass refining. Journal Industiral Microbiology Biotechnology, v. 35, n. 5, p. 393-402, 2008.

$\mathrm{HU}, \mathrm{Z}$. et al. Removal of congo red from aqueous solution by cattail root. Journal of Hazardous Materials, v. 173, n. 1-3, p. 292297, 2010.

MAHAMADI C. Water hyacinth as a biosorbent: a review. African Journal of Environmental Science and Technology, v. 513, n. 13, p. 1137-1145, 2011.

OFOMAJA, A. E.; HO, Y. Equilibrium sorption of anionic dye from aqueous solution by palm kernel fibre as sorbent. Dyes and Pigments, v. 74, n. 1, p. 60-66, 2007.

RENGANATHAN, S. et al. Kinetic studies on sorption of basic dye using eichhornia crassipes. Journal of Environmental Science and Engineering, v. 50 , n. 1 , p. $249-254$, 2008. 
SALLEH, M. A. M. et al. Cationic and anionic dye adsorption by agricultural solid wastes: a comprehensive review. Desalination, v. 280, n. 1-3, p. 1-13, 2011.

SANTANA, S. A. A. et al. Immobilization of ethylenesulfide on babassu coconut epicarp and mesocarp for divalent cation sorption. Journal of Hazardous Materials, v. 174, n. 1-3, p. 714-719, 2010.

SCULTHORPE, C. D. The biology of aquatic vascular plants. Königstein/West Germany: Koeltz Scientific Books 1985.

TARAWOU, T.; HORSFALL, M. J.; VICENTE, J. L. Adsorption of methyl red by water-hyacinth (eichhorni acrassipes) biomass. Chemistry \& Biodiversity, v. 4, n.1, p. 2236-2245, 2007.

TSERKI, V. et al. Novel biodegradable composites based on treated lignocellulosic waste flour as filler: part I, surface chemical modification and characterization of waste flour. Composites: Part A, v. 36, n. 7, p. 965-974, 2005.

TUNÇ, Ö.; TANACI, H.; AKSU, Z. Potential use of cotton plant wastes for the removal of remazol black $B$ reactive dye. Journal of Hazardous Materials, v. 163, n. 1, p. 187198, 2009.

VIEIRA, A. P. et al. Copper sorption from aqueous solutions and sugar cane spirits by chemically modified babassu coconut (orbignya speciosa) mesocarp. Chemical Engineering Journal, v. 161, n. 1-2, p. 99$105,2010$.

VIEIRA, A. P. et al. Epicarp and mesocarp of babassu (orbignya speciosa): characterization and application in copper phtalocyanine dye removal. Journal of the Brazilliam Chemical Society, v. 22, n. 1, p. 21-29, 2011. 